\title{
ADMINISTRATIVE DISCRETION, JUDICIAL REVIEW, AND THE GLOOMY WORLD OF JUDGE SMITH
}

\author{
RONALD M. LEVIN*
}

The diurnal cycle of administrative law metaphors moves steadily forward: first came "government in the sunshime," then "sunset" laws, and now the "twilight of administrative law." But have we really reached the end of the day for the fundamental assumptions on which our system of government rests? Judge Loren A. Smith's argument to that effect ${ }^{1}$ weaves together an interesting body of historical, theoretical, and practical learning. His essay provides an apt occasion for serious reflection on the developmg corpus of principles that we call administrative law. Not everyone, however, will reach conclusions as somber as his.

Judge Smith mamtains that our constitutional system is in trouble because of "judicialization." Administrative lawyers have, he believes, been influenced too much by their high regard for the judiciary and its methods. He asserts that this pervasive attitude has led to three undesirable trends. ${ }^{2}$ First, agencies have too frequently been forced to use formal procedures derived from the model of a courtroom trial. Second, agencies have been forced to accommodate the interests of too many players in the regulation game; the result is that some agencies' proceedings have becoine inordinately complex. ${ }^{3}$ Third, agencies have been forced to share policymaking power with judges, whose review of the merits of administrative actions has become too intrusive.

This comment focuses on the third of these clains. I will contend that searching and serious judicial review of the substance of administrative actions-a phenomenon soinetinies known as "hard look" review4-

* Professor of Law, Washington University. Professors Mathew McCubbins and Barry Weingast may claim credit for, while avoiding blame for, many of the "public choice" ideas in Part II of this comment.

1. Smith, Judicialization: The Twilight of Administrative Law, 1985 DUKE L.J. 427.

2. See id. at $428-29$.

3. I do not see why Judge Smith characterizes the increasing complexity of the administrative process as part of a trend toward "judicialization." It is unclear that court proceedings, as a group, are more complicated than agency proceedings. I will not expand on my doubts here, however, because this aspect of Judge Smith's critique is not the subject of this comment.

4. See National Lime Ass'n v. EPA, 627 F.2d 416, $451-52$ n.126 (D.C. Cir. 1980) (chronicling the changing connotations of the phrase "hard look"). 
is, on the whole, a durable and legitimate feature of the current scene. My argument does not mean that all reversals of agency actions are well founded, nor even that the case law as a whole shows as much deference as one imight desire. Judge Smith's critique of judicial review is valid up to a point. But judicial review also has virtues that Judge Sımith scarcely acknowledges, if at all. My purpose here is to evaluate his criticisms and to present what may be a more balanced perspective on the relationship between courts and agencies.

\section{Judicial Review Doctrine and the Smith CRitique}

\section{A. The Complexity of "Decisions of Will."}

At the heart of Judge Smith's essay is a distinction between two types of government action: "decisions of will" and "decisions of logic."5 Into the first category, he says, fall decisions that might also be termed pohitical, democratic, or pohicy decisions. ${ }^{6}$ They "typically are subjective. There is often no 'right' answer to the problem calling for such a decision. A classic, albeit homely [sic], example is whether the fence around the city hall should be painted blue or white. We summarize this concept by the term "discretion." "7 The second category, "decisions of logic," refers to governmental choices that can be made on an objective basis, such as whether a given individual has reached the legally designated voting age. These decisions may also, according to Judge Smith, be termed "legal" or "judicial" decisions. ${ }^{8}$

Judge Simith beheves that it is simply unjudicial for courts to involve themselves in decisions of will. Indeed, they are "constitutionally bound to disclaim [such a] role." 9 Decisions of will call for creativity like that of a scientist or engineer, he says; the reasoning processes of the courts, in contrast, are geared toward restraining human conduct through legal norms. "The courts, ... unlike the executive or legislative branches, can act only within the mode of law. ... Thus, while political bodies have the potential to be creative, courts must always be instruments of restraint. The judicial function begins where the democratically-controlled process of policy formation ends." 10 This sense of the fundamental illegitimacy of judicial pohicymaking figures prommently in Judge Smith's conclusion that administrative law is entering a "twilight" phase. He looks forward to a "dawn" in which the constitutional func-

\footnotetext{
5. Smith, supra note 1 , at 430 .

6. Id.

7. Id.

8. Id.

9. Id. at 429 .

10. Id. at 445 .
} 
tions of the three branches of our government will have been rethought. ${ }^{11}$ In a sound constitutional order, he suggests, the courts would be far less active. ${ }^{12}$

Judge Smith's antithesis between "decisions of will" and "decisions of logic" is, I believe, the source of many of the difficulties with his analysis. The concept of a "decision of will" carries at least a mild implication that when an agency must clioose from among a wide range of policy options, it ouglit to be free to ignore "legalistic" or "judicial" modes of thouglit entirely. Judge Smith does, to be sure, mention an "inevitable overlap" between the realms of will and logic. ${ }^{13}$ Even witl that qualification, however, his terminology fosters an image of two basically discrete categories of agency action.

In my view, this picture obscures the complexity of what we mean by discretionary administrative autliority. The vast majority of agency actions fall into an intermediate zone in which both "will" and "logic" have roles to play. In otler words, im the typical case Congress lias granted officials some rooin to maneuver, but still expects that the ultimate agency action will constitute a good-faith application of criteria found im the authorizing statute. ${ }^{14}$ Even largely discretionary decisions, therefore, will typically entail the sort of "logical" reasoning that a court potentially could evaluate.

Admittedly, the alternative model that I lave just outlined does not describe all administrative actions, such as those which are products of inherent executive autliority ${ }^{15}$ or which are, in the teclinical language of the Administrative Procedure Act (APA), "committed to agency discretion by law."16 When Judge Smith refers to decisions of will, lowever, he does not seem to be referring only to these narrow classes of cases. Rather, le seems to have in mind a mucli wider universe of situationsones in which an agency simply is operating under a broad grant of dis-

11. Id. at 466.

12. See id. at 465 ("IS]ubstantive judicial activism can be traced to the lack of a coherent and generally accepted theory on the limits and functions of the administrative statc.") (emphasis in original).

13. Id. at 430.

14. See L. JAFFe, Judicial Control of Administrative Action 555-56 (1965).

15. See Dames \& Moore v. Regan, 435 U.S. 654, 678-88 (1981) (discussing President's authority to suspend private claims against foreign governments as incident to resolution of foreign policy dispute).

16. 5 U.S.C. § 701(a)(2) (1982); see Citizens to Preserve Overton Park, Inc. v. Volpe, 401 U.S. 402,410 (1971) (section 701(a)(2) applies "in those rare instances where "statutes are drawn in such broad terms that in a given case there is no law to apply" "). Even in the absence of statutory constraints, however, abuse-of-discretion review remains feasible (although the Court has been reluctant to acknowledge as much). See $5 \mathrm{~K}$. Davis, Administrative Law Treatise $\S 28: 8$ (2d ed. 1984). 
cretionary authority. It is unhealthy to assume, even as a theoretical starting point, that agencies that possess such a grant should generally be free to behave exactly as they please. ${ }^{17}$

Given that decisions of will ordinarily call for an exercise of reasoning from considerations prescribed by statute, one can readily discern two ways in which courts might evaluate these decisions. They could inquire whether the agency correctly understood the statutory prenises, and also whether the agency reasoned from them in an acceptable manner. Of course, both types of inquiries are common in prevailing practice. They are known more familiarly as legal review and abuse-ofdiscretion review. The renainder of this section will suggest that each has a legitimate role to play. This discussion, obviously, will be extreinely compressed; the reader who is interested in a detailed examination of current doctrines on the scope of judicial review of admimistrative action will have to look elsewhere. ${ }^{18}$

\section{B. Legal Issues.}

At the very least, an agency's possession of broad discretionary authority should not shield its rules and orders from being reviewed for errors of law. ${ }^{19}$ The easiest case, conceptually speaking, arises when an agency action is alleged to be ultra vires on its face. ${ }^{20}$ In fact, a case of this sort approaches what Judge Smith calls a "decision of logic," be-

17. Even in the "classic" example that Judge Smith uses to exemplify the decision of will"whether the fence around the city hall should be painted blue or white," Smith, supra note 1, at 430-the administrator's choice could conceivably be constrained by "aesthetic zoning" laws. See Berman v. Parker, 348 U.S. 26, 33 (1954) (dictum) ("It is within the power of the legislature to determine that the community should be beautiful as well as healthy ...."); Maher v. City of New Orleans, 516 F.2d 1051, 1054 \& n.5, 1061 (5th Cir. 1975) (sustaining ordinance that imposed color and other restrictions on structures in historic district), cert. denied, 426 U.S. 905 (1976); City of Santa Fe v. Gamble-Skogmo, Inc., 73 N.M. 410, 419, 389 P.2d 13, 19 (1964) (same).

18. The ABA Section of Administrative Law, in a project with which I was associated, has recently conipleted action on a "restatenient" of doctrines in this area. See Levin, Scope-of-Review Doctrine Restated: An Administrative Law Section Report, 38 AD. L. REv. 239 (1986) [hereinafter Restatement Report].

19. The following discussion emphasizes judicial review of alleged breaches of statutes, but the analysis of review for other errors of law would be similar. Presumably, for example, Judge Smith would acknowledge the permissibility of review for constitutional violations. $C f$. Smith, supra note 1 , at $428 \mathrm{n} .2$ (citing literature on proper use of Constitution).

20. For examples of agency actions set aside as ultra vires on their face, see Board of Governors v. Dimension Fin. Corp., 106 S. Ct. 681 (1986) (Federal Reserve Board has no authority over "nonbank banks"); Lowe v. SEC, 105 S. Ct. 2557, 2571 (1985) (Investment Advisers Act does not authorize SEC to enjoin regular distribution of investment advice by disinterested newsletter publisher); Public Serv. Comm'n v. Mid-Louisiana Gas Co., 463 U.S. 319, 338 (1983) (FERC lacked authority under Natural Gas Policy Act of 1978 to exclude pipeline production from statutory pricing scheme). 
cause the challenger's claim, in effect, is that the statute gave the agency absolutely no discretion to adopt the rule or order in question.

As suggested by the discussion above, however, the inquiry into facial validity does not exhaust the court's function in reviewing for errors of law. Thoughtful commentators have long emphasized ${ }^{21}$ that one integral aspect of this function is to determine whether the agency acted without using the analytical framework prescribed by Congress. ${ }^{22}$ For example, a few years ago the Court read the Occupational Safety and Health Act to require that federal regulations governing toxic substances in the workplace must be set at the highest level of protection that is technologically and economically feasible; thus, if OSHA were to choose a level of protection for a given substance by employing an ad hoc costbenefit analysis, its rule would be invalid. ${ }^{23}$

Now, while one might disagree with the Court's construction of the Act, ${ }^{24}$ it is difficult to see why this type of judicial oversight should be considered an illegitimate intrusion upon agency autonomy-even though OSHA's safety rules are to a very considerable degree "decisions of will." The reviewing court's inquiry is simply a sophisticated form of statutory construction. To be sure, inuch case law urges courts to give weight to an agency's views on the ineaning of the statute it enforces. ${ }^{25}$ Ultimately, however, statutory interpretation is usually considered a judicial responsibility in administrative law, just as in all other realms of our legal system. ${ }^{26}$

21. See G. Henderson, The Federal Trade Commission 96-98 (1924); L. JAFFe, supra note 14, at 181-82; Byse, The Availability and Scope of Judicial Review of Administrative Action by Ordinary Courts, in LAW IN THE UNITED STATES OF AMERICA IN SOCIAL AND TECHNOLogical REVolution 543, 564-67 (J. Hazard \& W. Wagner eds. 1974); Stern, Review of Findings of Administrators, Judges and Juries: A Comparative Analysis, 58 HARv. L. REv. 70, 105 (1944).

22. For examples of agency actions set aside because the agency failed to follow the analysis prescribed by Congress, see NLRB v. International Longshoremen's Ass'n, $105 \mathrm{~S}$. Ct. 3045, 3056-57 (1985) (Board incorrectly considered extra-unit effects of work preservation agreements in evaluating their validity); Dirks v. SEC, 463 U.S. 646 (1983) (SEC used incorrect test in determining whether tippee was liable for insider trading); Industrial Union Dep't, AFL-CIO v. American Petroleum Inst., 448 U.S. 607, 642-46 (1980) (plurality opinion) (OSHA failed to make statutorily required finding that toxic substances to be regulated created a "significant risk").

23. American Textile Mfrs. Inst. v. Donovan, 452 U.S. 490, 506-22 (1981) (construing Occupational Safety and Health Act of 1970, 29 U.S.C. $\S 655$ (1980)).

24. See Industrial Union Dep't, AFL-CIO v. American Petroleum Inst., 448 U.S. 607, 667-71 (1980) (Powell, J., concurring) (rejecting the view Court later adopted in Ameriean Textile Mfrs. Inst. v. Donovan, 452 U.S. 490 (1981)).

25. See, eg., FDIC v. Philadelphia Gear Corp., 106 S. Ct. 1931, 1938-39 (1986); FEC v. Democratic Senatorial Campaign Comm., 454 U.S. 27, 39 (1981).

26. The courts' use of substantially independent judgment in reviewing agencies' statutory interpretations is defended on the basis of the Constitution in Levin, Identifying Questions of Law in Administrative Law, 74 GEo. L.J. 1, 16-22 (1985); Monaghan, Marbury and the Administrative State, 83 Colum. L. Rev. 1 (1983). These analyses answer, at least to some extent, what Judge 
Actually, Judge Smith does not directly challenge these conventionally accepted principles. Instead, he focuses on background forces that, in his view, tend to convert the courts' role as statutory interpreters in regulatory cases into a policyınaking role. Muclı of the blaine, he thinks, rests with Congress, which "has contributed to the limiting of agency discretion ... [by] granting . . . broad substantive mandates to the agencies to fulfill their statutory purposes." $27 \mathrm{He}$ admits that this claim is paradoxical, but goes on to explain that gaps left by the legislature will be filled by the courts: "Judicial review becomes far more important in defining the direction and meaning of a statute when that statute sets out vague and possibly self-contradictory inandates to an agency, rather than clear or simple directives that leave hittle room for any judicial doubt as to the agency's mission."28 Congress's broad statutory inandates thus encourage courts to become "arbiters . . . of agency pohicy direction."29

Read at face value, Judge Smith's discussion is fallacious, because it incorrectly equates statutory breadth witl statutory vagueness, or ambiguity. After all, a regulatory mandate can be broad witliout being ambiguously worded. When this is the case, the courts-at least theoretically-must respect the legislature's desire to give the agency sweeping authority. ${ }^{30}$ Of course, no one has found a foolproof way to prevent judges from imposing their value preferences under the pretense of statutory interpretation; ${ }^{31}$ but it is ambiguity, not breadth, that creates the potential for "judicial legislation." Indeed, ambiguity can certainly exist even when the authority that a statutory provision has granted is basically ministerial. ${ }^{32}$

It may be, however, that in the passage under examination Judge Smitl is not addressing "statutory interpretation" in a strict sense. This hypothesis draws support from the fact that this passage introduces his discussion of the Supreme Court's 1983 decision in Motor Vehicle Manu-

Smith perceives as a "need to sort out anew the constitutional powers of the branches of the federal government." Smith, supra note 1 , at 466.

27. Smith, supra note 1 , at 452 .

28. Id. (footnote omitted).

29. Id.

30. See Garland, Deregulation and Judicial Review, 98 HARv. L. REv. 505, 558-60 (1985).

31. Suspicions that judicial review of administrative action is fundamentally "result-oriented" remain prevalent. See, e.g., Bruff, Legislative Formality, Administrative Rationality, 63 TEx. L. REv. 207, 239 (1984); Shapiro, APA: Past, Present, Future, 72 VA. L. REv. 447, $478-79$ (1986). For a firm denial from one of the alleged manipulators, see Edwards, Public Misperceptions Concerning the "Politics" of Judging: Dispelling Some Myths About the D.C. Circuit, 56 U. CoLO. L. REv. 619 (1985).

32. See, e.g., United States v. Locke, $105 \mathrm{~S}$. Ct. 1785, 1789-91 (1985) (ambiguity in statute prescribing filing deadline); Heckler v. Turner, $105 \mathrm{~S}$. Ct. 1138, 1144 (1985) (ambiguity in statutory formula for calculating eligibility for AFDC benefits). 
facturers Association v. State Farm Mutual Automobile Insurance Co. ${ }^{33}$ In State Farm the Court overturned the decision of the National Highway Traffic Safety Administration (NHTSA) to rescind a regulation requiring automobile conıanies to install "passive restraints"-either airbags or automatic seatbelts-im newly manufactured cars. The decision turned on an application of abuse-of-discretion doctrine, not statutory interpretation. Thus, Judge Smith's real complaint may be that broad statutes foster judicial policymaking because they leave so much rooin for courts to use abuse-of-discretion review to overturn agency decisions of will. If this is what he means, his warning has some substance and requires examination in a different context.

\section{Abuse of Discretion Review.}

Few would argue that the manner in which an agency exercises its discretionary power should receive no judicial scrutiny at all. After all, the Congress that enacted the APA nust have nieant something when it directed reviewing courts to set aside not only those agency actions which violate statutory rights, ${ }^{34}$ but also those which are "arbitrary, capricious, an abuse of discretion, or otherwise not in accordance with law."35 If NHTSA were to promulgate an automobile safety standard that was technologically impossible (for example, "All cars on the road nust be equipped with airbags by three months from today") or grotesquely harsh (for example, "Anyone caught driving with his seat belt unbuckled shall forfeit his car"), niost people would expect the courts to step in, even if the underlying legislation could not be interpreted to foreclose the issuance of such a rule. ${ }^{36}$

33. 463 U.S. 29 (1983).

34. 5 U.S.C. $\S 706(2)(C)$ (1982).

35. Id. $\S 706(2)(\mathrm{A})$.

36. "Abuse-of-discretion review," as the term is used in this comment, means review to determine whether an agency action should be set aside on a basis other than that the agency misconstrued, or might have misconstrued, a statute (or other source of binding law). For an overview of the types of errors that constitute abuses of discretion, see Restatement Report, supra note 18, at 253-60. Although this type of review was originally rationalized on the ground that an unreasonable agency action was in substance a violation of the statute under which the agency acted, see ICC $v$. Illinois Cent. R.R., 215 U.S. 452, 470 (1910), that fictional argument should be considered unnecessary today. See L. JAFFE, supra note 14, at 263-66. Legislative authorization for abuse-of-discretion review, if considered essential, can be found in section 706(2)(A) of the APA. That authorization disappears, of course, where the regulatory scheme affirmatively disallows review of the agency's reasoning process. See, e.g., Adamo Wrecking Co. v. United States, 434 U.S. 275, 285 (1978) (Clean Air Act precludes abuse-of-discretion review of certain emission standards during enforcement proceedings). 
While apparently willing to accept that type of abuse-of-discretion review, ${ }^{37}$ Judge Smith warns against another type-judicial intervention based on asserted deficiencies in an agency's reasoning process. In his view, "[t] here is no bright line between a judicial challenge to an agency's reasoning-given that the agency does not purport to be engaged in a decision of logic-and a court's 'substi[tution of] its judgment for that of the agency." "38 He illustrates his warning with the agency decision overturned in State Farm, which was not remotely as egregious as the hypothetical rules described in the preceding paragraph. Judge Smith draws attention to the Court's remark in that case that an agency issuing a rule "must examine the relevant data and articulate a satisfactory explanation for its action." 39 This language, he points out, "is itself so broad a standard that it can be used ... to intrude into the realm of legitimate discretionary agency decisionmaking." 40

Judge Smith's underlying concerns are valid. Courts surely have an obligation to exercise considerable restraint when they review an agency action for abuse of discretion. By definition, such review entails an examination of poticymaking that Congress has entrusted primarily to the agency. The great question posed by abuse-of-discretion review is whether courts can successfully accommodate these concerns while also trying to upgrade the "rationality" of administrative decisionmaking. The general strategy the courts have adopted is to articulate some fairly lenient requirements that are designed to intercept the most blatantly irrational agency decisions-ones that fail to display even minimal regard for facts, logic, agency precedent, etc.

State Farm, Judge Smith's principal example of overly intrusive review, demonstrates this strategy at work. The point that emerged as crucial in State Farm was that NHTSA, in promulgating its original passive restraints rule in 1977, had found both airbags and automatic seatbelts to be workable and cost-effective methods of saving lives on the highways. ${ }^{41}$ In its 1981 order rescinding that rule, NHTSA declared that the "detachable" seatbelt then favored by auto manufacturers would be ineffective. It did not discuss the effectiveness of airbags at all, however, and its comments on the "nondetachable" seatbelts that it had endorsed four years

37. See Smith, supra note 1, at 454 (apparently condoning reversal of "egregiously" arbitrary acts).

38. Id. (quoting State Farm, 463 U.S. at 43).

39. State Farm, 463 U.S. at 43.

40. Smith, supra note 1 , at 454 .

41. State Farm, 463 U.S. at 35 (referring to NHTSA's 1977 estimate that passive restraints could prevent 12,000 deaths and 100,000 serious injuries annually, 42 Fed. Reg. 34,289, 34,298 (1977)). 
earher were limited to three cursory paragraphs of analysis. ${ }^{42}$ In holding the rescission invalid, the Court unanimously concluded that, in view of NHTSA's earher approval of the airbag and nondetachable seatbelt options, the agency should at least explain why it was now taking action that in effect treated those options as worse than doing nothing. ${ }^{43}$

Thus, even though State Farm did, as Judge Sinith noted, call in general terms for "satisfactory explanation[s]" of agency rules, ${ }^{44}$ the holding and specific rationale of the case do not conimit the Court to supporting the broadest possible applications of that language. Nor did the Court squarely adopt the primciple, advanced in soine earlier decisions in lower courts, ${ }^{45}$ that an agency inay not adopt a new policy without careful examination of all significant alternatives. ${ }^{46}$ Precision in stating the scope of the Court's holding is worthwhile, because the duty that the unaminous Court did recognize-a duty to explain departures froin the agency's own prior views-is much inore inanageable than the broader formulations just mentioned. ${ }^{47}$ The precise holding conveys to agencies a relatively clear message about what is expected from thein, and it permits courts to exercise some supervision over one species of potentially arbitrary action without having to resort to overt substitution

42. 46 Fed. Reg. 53,419, 53,421-22 (1981).

43. See State Farm, 463 U.S. at 46-51, 55-57. Five Justices also concluded that NHTSA's belief in the ineffectiveness of detachable belts was unsupported by the record. Id. at 51-55. This was the only holding with which the dissenters disagreed. See id. at 57-58 (Rehnquist, J., dissenting).

44. See supra note 39 and accompanying text.

45. See, e.g., Office of Communication of United Church of Christ v. FCC, 707 F.2d 1413, 1426 (D.C. Cir. 1983); Action on Smoking \& Health v. CAB, 699 F.2d 1209, 1216 (D.C. Cir. 1983); Pillai v. CAB, 485 F.2d 1018, 1027 (D.C. Cir. 1973).

46. The District of Columbia Circuit has suggested that the Court did impose a general requirement that alternatives must be evaluated. See ILGWU v. Donovan, 722 F.2d 795, 817 (D.C. Cir. 1983) ("reasoned decisionınaking" inandated by State Farm necessitates consideration of reasonable alternatives, although not of uncommon or unknown alternatives), cert. denied, $105 \mathrm{~S}$. Ct. 93 (1984). I believe that the Court explicitly declined to require this:

Nor do we broadly require an agency to consider all policy alternatives in reaching decision.... [T] he airbag is more than a policy alternative to the passive restraint Standard; it is a technological alternative within the ambit of the existing Standard. We hold only that given the judgment made in 1977 that airbags are an effective and cost-beneficial lifesaving technology, the mandatory passive-restraint rule may not be abandoned without any consideration whatsoever of an airbags-only requirement.

State Farm, 463 U.S. at 51. On the other hand, nothing in the Court's opinion prohibits the D.C. Circuit from adhering to its prior case law requiring consideration of alternatives, as indeed it has done. See Walter O. Boswell Memorial Hosp. v. Heckler, 749 F.2d 788 (D.C. Cir. 1984); Farmers Union Cent. Exch., Inc. v. FERC, 734 F.2d 1486, 1511 (D.C. Cir.), cert. denied, 105 S. Ct. 507 (1984); ILGWU v. Donovan, 722 F.2d at 815-18. Other circuits have not yet explicitly embraced this requirement.

47. Cf. Brae Corp. v. United States, 740 F.2d 1023, 1038 (D.C. Cir. 1984) (State Farm test does not entail "heightened scrutiny" but is simply a variation on familiar abuse- of-discretion analysis), cert. denied, 105 S. Ct. 2149 (1985); Black Citizens for a Fair Media v. FCC, 719 F.2d 407, 417 n.25 (D.C. Cir. 1983) (similar), cert. denied, 467 U.S. 1255 (1984). 


\section{of judicial for executive value judgments. ${ }^{48}$}

Judge Smith overstates his case, therefore, when he depicts reviewing courts as inevitably turning into "arbiters . . . of agency pohicy direction." 49 It is true enough that there is "no bright line" between abuse-ofdiscretion review and outright displacennent of the agency's discretion. Careless or overbroad articulation of the apphicable standards of review may well have fostered improper intrusions, as Judge Smith beheves. ${ }^{50}$ But contemporary abuse-of-discretion doctrine has been taking shape for only about fifteen years, ${ }^{51}$ and the Supreme Court has been proceeding

48. Judge Smith sees little reason why the Court should have demanded an explauation for the agency's change in view: It is "as if the Administration was not fully aware that it was overturning the previous policy." Smith, supra note 1, at 453-54. To understand this acid remark, a bit of history is necessary. Originally, the duty to explain departures from prior policy was defended as a way of making sure that the agency itself had thought about what it was doing: "An agency's view of what is in the public interest may change, either with or without a change in circumstances. But an agency changing its course must supply a reasoned analysis indicating that prior policies and standards are being deliberately changed, not casually ignored . . . Greater Boston Television Corp. v. FCC, 444 F.2d 841, 852 (D.C. Cir. 1970) (per Leventhal, J.) (footnotes omitted), cert. denied, 403 U.S. 923 (1971). More recently, however, abuse-of-discretion doctrine has come to be viewed as having an additional, more substantive dimension. This change in emphasis has been described as a shift from the "agency hard look," see id. at 853, towards a "judicial hard look." See National Lime Ass'n v. EPA, 627 F.2d 416, 451-52 n.126 (D.C. Cir. 1980); Garlaud, supra note 27, at 525-45. Significantly, when the Court in State Farm quoted the above langnage from Greater Boston, it deleted the last portion ("deliberately changed, not casually ignored") of Judge Leventhal's remark, thus avoiding any implication that an agency's abandonment of prior policy is legitimate whenever it occurs "deliberately." 463 U.S. at 57.

49. Smith, supra note 1, at 452; see also id. at 456 ("[W] [Wen [agencies] come up with decisions significant elements of the society do not like, we shift the decisions to judicial bodies....") (emphasis added).

In a similar vein, Judge Sinith argues that a court acquires "at least temporary control over substantive policy" when it remands an administrative decision because of deficiencies in the reasouing supporting the action. Id. at 454 (emphasis added). The criticism does not cut very deep, because "control" in this sense temporarily shifts when a court remands au administrative decision for any reason at all. This truism should not distract attention from the central issue: to decide what principles ought to govern substantive judicial review of administrative action. Wheu the courts are applying proper standards of review, administrators who lose "control" over policy have only themselves to blame.

50. The ABA Administrative Law Section recognized in its restatement of scope-of-review doctrine that the case law currently allows a court to set aside an agency action that "fails . . to rest upon reasoned decisionmaking." Restatement Report, supra note 18, at 259-60. Because some lawyers commenting on early drafts expressed coucern about this open-ended ground of decision, however, the accompanying report included an explicit warning that the restatement's recognition of this line of authority "is not intended to imply a firm endorsement of it." Id. at 260. Strictly speaking, this disclaimer was superfluous, since the eutire restatement was designed to be basically descriptive, but even superfluity can convey a message.

51. A convenient measuring point for the beginning of the hard look doctrine is the nearly simultaneous appearance of three important decisions: Citizens to Preserve Overton Park, Inc. v. Volpe, 401 U.S. 402 (1971); Environmental Defense Fund, Inc. v. Ruckelshaus, 439 F.2d 584 (D.C. Cir. 1971); and Greater Boston Television Corp. v. FCC, 444 F.2d 841 (D.C. Cir. 1970), cert. denied, 403 U.S. 923 (1971). 
with the utmost caution. Indeed, what may be most noteworthy about State Farm is that it was atypical; it was apparently the first time in a decade that the Court had used a pure abuse-of-discretion rationale to strike down a federal agency's decision. ${ }^{52}$ Consequently, it is far too early to conclude that judicial scrutiny of the reasons agencies give for their discretionary choices has proved unworkable. Instead, the search for moderate, durable scope-of-review principles should continue.

\section{The Democracy ISSUE}

As I have discussed, Judge Smith's contention that the modern judicial hard look unduly restricts agency discretion stems largely from an oversimplified formal model of the courts' capabilities. But his doubts about the courts' capabilities are not the only basis for his discontent. $\mathrm{He}$ also beheves that active judicial review of "decisions of will" corrodes the democratic process. ${ }^{53}$ In this section of the comment, I will respond to this branch of his analysis.

Judge Smith's discussion of the tension between judicial review and democracy is not the account that one might have expected. According to the usual description of this tension, courts interfere too readily with the policies of Congress, either by misconstruing statutes or by wrongly holding them unconstitutional. But that familiar complaint of disgruntled politicians and acerbic commentators is not the point Judge Smith wishes to make. Rather, he fears that the very existence of vigorous judicial review of agency actions deters Congress from reaching policy decisions in the first place. He argues that legislators, when asked to make difficult choices between conflicting social goals, are prone to take the easy way out by delegating to administrative agencies. They can thereby claim credit for "doing something" about the problem, without later having to take the blame for the agency's concrete decision. Recognizing that the courts will closely scrutinize the agency's actions, legislators are content to allow the supposedly nonpolitical judiciary to make decisions

52. In this comment's usage, as discussed supra note 36 , an abuse-of-discretion reversal occurs when a court sets aside an agency action without concluding that the agency misunderstood the law. Before State Farm, the most recent Supreme Court case using pure abuse-of-discretion reasoning to invalidate an agency action was Atchison, T. \& S.F. Ry. v. Wichita Bd. of Trade, 412 U.S. 800, 80617 (1973) (agency failed to articulate reasoned justification for departure from prior policies). Even in that case, it was unclear whether the lead opinion spoke for a majority of the Court. See id. at 826 (Douglas, J., concurring and dissenting).

One additional abuse-of-discretion reversal has come down since State Farm. Again, however, only a plurality of Justices joined the lead opinion. See Bowen v. American Hosp. Ass'n, 106 S. Ct. 2101, 2114-17, 2121-22 (1986) (opinion of Stevens, J.) (striking down "Baby Doe" rules, primarily because of lack of factual support for government's theories). The swing voter, Chief Justice Burger, concurred in the result without opinion. Id. at 2123.

53. See Smith, supra note 1, at 446. 
that Congress should have made. ${ }^{54}$

Judge Smith's view that delegation is at least partly a congressional blame-avoiding strategy is echoed by many other observers 55 and is especially prominent in the modern "public choice" literature. ${ }^{56}$ For the sake of discussion we nnay take this view as true and further assuine, as its proponents generally do, that Congress's fondness for delegation sliould be deplored (although that proposition is by no means self-evident). ${ }^{57}$ Even if these premises are accepted, they do not support Judge Smitl's conclusion that courts are reviewing "decisions of will" too actively.

Judge Smitli's diagnosis of congressional behavior might warrant some reduction in hard look review if sucli a reduction would be likely to cause Congress to inake more policy decisions on its own. This seems fairly unlikely, lowever. Even if judicial review became less intrusive, most of the factors that now lead Congress to delegate authority would continue to exert their influence. These include the tremendous volume of services that our society wants government to provide; the real or

54. Id. at 455-56. Judge Smith also contends that administrative law interferes with deinocracy by enticing the public into believing that procedure is inore important than substance. $\mathrm{Ab}$ sorbed with the question whether due process was observed, society refrains from seriously evaluating whetler regulators' clioices conform to our political and moral heritage. See id. at 429, 456, 465. Although the "procedural" aspect of "judicialization," see supra text accompanying notes $2-3$, nay be vulnerable to this criticism, activist judicial review surely is not. Rather, it induces officials and litigants to focus more attentively on the substantive merits of agency policies.

55. See, e.g., Industrial Union Dep't, AFL-CIO v. American Petroleum Inst., 448 U.S. 607, 687 (1980) (Rehnquist, J., concurring) (calling Congress's delegation in that case an "obvious example of Congress simply avoiding a choice which was both fundamental . . . and yet so politically divisive that the necessary decision or compromise was difficult, if not impossible, to hammer out in the legislative forge."); J. ELY, DEMOCRACY AND Distrust 131-32 (1980); Wiltse, The Representative Function of Bureaucracy, 35 AM. Pol. ScI. ReV. 510, 514-15 (1941).

56. See, e.g., M. FIORINA, CONGRESS: Keystone OF THE WASHINGTON ESTABLISHMENT 4849 (1977); Aranson, Gellhorn \& Robinson, $A$ Theory of Legislative Delegation, 68 CoRNELL L. REV. 1, 56-62 (1982); Fiorina, Legislative Choice of Regulatory Forms: Legal Process or Administrative Process?, 39 PuB. CHorce 33, 46-52 (1982).

57. In a valuable recent article, Jerry $L$. Mashaw questions tlie conventional belief that delegations by Congress should be viewed with suspicion. Mashaw, Prodelegation: Why Administrators Should Make Political Decisions, 1 J.L. ECON. \& ORGANIZATION 81 (1985). Although his treatment is too extensive for a full summary here, the contention that may be most relevant to the present discussion is that delegations do not actually interfere with legislative accountability. Mashaw argues that the decision to delegate is itself a clioice for which legislators could be held accountable if the electorate really objected to it. $I d$. at 87 . Moreover, voters are inore likely to care about their representative's general ideological tendencies than about a specific issue position that the representative would have taken if there had been no delegation. Id. at 87-88; see also infra note 77 .

This is not to say tliat Judge Smith's attitude should be dismissed entirely. Undoubtedly, many people are attracted to the notion that Congress should, whenever possible, make fundamental regulatory decisions on its own. In some abstract sense, our governmental system is "supposed" to work that way. See, e.g., Industrial Union Dep't, AFL-CIO v. American Petroleum Inst., 448 U.S. 607, 685-86 (Rehnquist, J., concurring). Mashaw's article does establish, however, that the disfavored status of delegation deserves more careful consideration than it usually receives. 
imagined benefits of leaving that work to experienced and technically sophisticated "experts"; and the desire to establish programs that can be flexibly administered in differing settings across the nation. ${ }^{58}$ Even the blame-avoiding strategy described by Judge Smitlı would not necessarily lose its attraction: Congress could merely start blaming courts less frequently and agencies more frequently. In sliort, a new regime of judicial deference would probably not cause Congress to cease delegating autliority broadly. It would more likely result in a greater concentration of delegated authority in the liands of administrative officials who themselves have no electoral mandate. Shifting power from unelected judges to unelected bureaucrats does not sound like an effective way to enliance democratic control over social policy.

The reasoning just offered is incomplete, lowever. Implicit in Judge Smitl's discussion may be a notion that intrusive judicial review also subverts the democratic process in a second way-not only by encouraging Congress to avoid difficult policy choices, but also by hampering the exercise of political judginent by the executive branch. After all, the executive agencies work closely with the White House and answer directly to it. 59 In recent years, moreover, their major proposed rules liave been imtensively examined by the Office of Management and Budget, whicl is cominitted to advancing the President's political agenda. ${ }^{60}$ These ties to the President make it likely that agencies will be more closely attuned to public sentiment than tlie "isolated" judiciary can be. It is fairly arguable, therefore, that the courts' standards of review should be lenient, so that agencies will be able to adopt policies the public wants. In the past few years, judicial deference has increasingly been promoted as a means of allowing an incumbent administration to act on the views that may have led the citizenry to elect it. ${ }^{61}$ This argument unquestionably lias a

58. See generally J. Landis, The Administrative Process 6-46 (1938); Breyer, The Legislative Veto After Chadha, 72 GEo. L.J. 785, 788 (1984) ("Congress delegated broadly to the agencies because it had to do so."); Mashaw, supra note 57, at 91-99.

59. "Independent" agencies are not supervised by the White House in the same way that executive agencies are, but their heads are often selected by the President for appointment because of the specific policies they would want to implement while in office.

60. See Exec. Order No. 12,498, 3 C.F.R. 323 (1986), reprinted in 5 U.S.C. $\S 601$ app. at 92 (Supp. III 1985); Exec. Order No. 12,291, 3 C.F.R. 127 (1982), reprinted in 5 U.S.C. $\$ 601$ app. at 431-34 (1982); DeMuth \& Ginsburg, White House Review of Agency Rulemaking, 99 HARv. L. REv. 1075 (1986); Morrison, OMB Interference with Agency Rulemaking: The Wrong Way to Write a Regulation, 99 HARV. L. REV. 1059 (1986).

61. See, e.g., Chevron U.S.A. Inc. v. Natural Resources Defense Council, 467 U.S. 837, 865-66 (1984); State Farm, 463 U.S. at 59 (Rehnquist, J., concurring and dissenting); Sierra Club v. Costle, 657 F.2d 298, 405-08 (D.C. Cir. 1981); Scalia, Rulemaking as Politics, 34 AD. L. REv. v (Summer 1982). But cf. National Black Media Coalition v. FCC, 775 F.2d 342, 356 n.17 (D.C. Cir 1985) ("While an agency may properly rely on an 'incumbent administration's views of wise policy to 
good deal of force. 62

Yet the interplay between judicial review and democracy should not be oversimplified. As a counterpoint to Judge Smith's plea for judicial restraint, I shall argue that, in certain ways, hard look review can actually strengthen the representativeness of modern government. It does this by helping to keep the executive branch accountable to other actors in the political systein, namely Congress and the voting public.

Judicial review for errors of law promotes accountability by enforcing statutes that are theinselves the products of a majoritarian process. For exainple, in the 1966 traffic safety legislation, as later construed by the Supreine Court, ${ }^{63}$ the people decided through their elected representatives that NHTSA should treat safety as the paramount consideration when writing motor vehicle standards. That a new conservative majority elected Ronald Reagan in 1980 should be relevant in the later administration of the statute, but only up to a point. It would be a legitimate basis for the exercise of discretion within the statutory framework. It wonld not, however, justify Reagan's NHTSA in issuing a rule predicated on the assumption that the goal of safety is less important than the financial health of the automobile industry. Judicial invalidation of such a rule would not be antidemocratic, but rather a vindication of the expressed will of the 1966 majority.

Judicial review for abuse of discretion can bolster the deınocratic process in a different way. It can foster informed political dialogue by counteracting the bureaucratic tendency to shy away from controversy. By reversing agency actions that are supported by blatantly weak reasoning, reviewiug courts can force an agency to state its case fairly to the public and be judged thereon. ${ }^{64}$ To return to the State Farm example, NHTSA evidently attempted to minimize public opposition to its decision by asserting that effective passenger protection simply conld not, as far as it knew, be achieved through a passive restraints rule. But when the courts made clear that this neutral-sounding explanation was incredible (because of the suspicious paucity of discussion of airbags and nondetachable belts, which had been deemed effective by NHTSA a few

inform its judgments,' [Chevron, 467 U.S. at 865](emphasis added), it may not casually substitute those considerations for a rational evaluation of the merits and efficacy of its policies.").

62. Two commentators who are generally sympathetic towards hard look review have suggested recently that the strengthening of executive oversight might ultimately warrant at least some narrowing of judicial oversight. See DeLong, New Wine for a New Bottle: Judicial Review in the Regulatory State, 72 VA. L. REv. 399, 419 (1986); Sunstein, Factions, Self-Interest, and the APA: Four Lessons Since 1946, 72 VA. L. REv. 271, 292-95 (1986).

63. See State Farm, 463 U.S. at 55.

64. See Garland, supra note 30, at 554-57; Sunstein, Deregulation and the Hard-Look Doctrine, 1983 SuP. CT. REV. 177, 211. 
years earlier), the agency had to choose between changing its policy and telling the public more candidly wly requiring devices that did work was nevertheless not in the public interest. Thus, while courts could not devise a passive restraints policy on their own, abuse-of-discretion review was properly employed to prevent a political choice from being concealed behind a technocratic facade. ${ }^{65}$

It might be objected that members of Congress, who possess their own electoral base, are far better qualified than the courts to monitor and at times challenge the executive branch's claims to be representing the popular will. The point is well taken but is not a complete answer. First, the oversight committees of Congress have limited time and resources. Although they may be more attentive than is soinetimes assumed, ${ }^{66}$ they inevitably will not know much about, or be prepared to do anything about, some of the policy positions agencies adopt. Judicial review, in contrast, may normally be invoked by anyone who is harmed by the agency action in question; ${ }^{67}$ contacts with well-positioned members of Congress are not needed. Interestingly, it also appears that Congress often obtains information for oversight purposes by consulting materials that the agency has drafted or assembled to ineet the requirements of judicial review. 68

Finally, one should not exaggerate how greatly Congress's qualifications exceed those of the judicial branch. Oversight committees are not always perfectly representative of Congress as a whole (let alone of the electorate). It is well known that the rosters of congressional committees tend to be heavily biased in favor of members whose home districts have a parochial interest in the committee's business. ${ }^{69}$ Furthermore, most of

65. Abuse-of-discretion review cannot always expose concealed motives, because a strong presumption of regularity usually prevents courts from probing beneath the surface of the written decision. See, e.g., Citizens to Preserve Overton Park, Inc. v. Volpe, 401 U.S. 402, 420 (1971); Restatement Report, supra note 18, at 264-67; see also Murphy, What Reason for the Quest?: A Response to Professor Scott, 42 U. CHr. L. REV. 299, 305-06 (1975) (one official's candid admission that agency opinion-writers will advance, sincerely or otherwise, any rationale that they think a court will uphold). Thus, judicial review will be effective only against explanations that are so illogical, inconsistent, factually unsupported, etc., that they cannot be seriously intended. But even that much benefit seems valuable.

66. See McCubbins \& Schwartz, Congressional Oversight Overlooked: Police Patrols Versus Fire Alarms, 28 AM. J. PoL. Scr. 166 (1984).

67. See 5 U.S.C. $\S 702$ (1982).

68. McCubbins, Noll \& Weingast, The Political Implications of Administrative Procedures, J.L. ECON. \& ORGANIZATION (forthcoming). According to congressional staff members surveyed in a recent study, government publications and notices are prime sources of oversight information (although the staffers also mentioned many other sources). Aberbach, The Congressional Committee Intelligence System, CONGRESS \& PRESIDENCY (forthcoming Spring 1987).

69. See, e.g., K. Shepsle, The Giant Jigsaw Puzzle: Democratic Committee AssignMENTS IN THE MODERN HOUSE 66-93, 231-32, 259-60 (1978). The Supreme Court's invalidation of the legislative veto in INS v. Chadha, 462 U.S. 919 (1983), may rest, in part, on a perception that a 
the actual work of oversight is not done by Senators and Representatives, but by committee staffers, whose pohtical accountability is indirect at best. $^{70}$ The uncertain reliability of congressional oversight is particularly significant when the issue is whether the executive brancli has properly interpreted its statutory mandate. On those issues, the courts are likely to give a more objective and dependable answer than individual members or committees of Congress would. ${ }^{71}$ Consequently, many agency policy judgments that do not trouble oversight committees will nevertheless raise serious questions that a court ought to address. ${ }^{72}$

To sum up, Judge Smith is riglit to maintain that one major test of the efficacy of a regulatory system is whether it is able to honor the policy preferences of the voting majority. ${ }^{73}$ This goal presumably should not be pursued to the complete exclusion of other goals, such as stability, efficiency, and evenhandedness, but its claims are impossible to overlook. Nevertheless, judicial passivity is not always the way to further it. The problem brings to mind a remark from Judge Leventhal's well-known concurring opinion in Ethyl Corp. v. EPA:74 "Congress has been willing to delegate its legislative powers broadly . . . because there is court review to assure that the agency exercises the delegated power within statutory limits, and that it fleshes out objectives within those limits by an admimistration that is not irrational or discriminatory." 75 He thus perceived the same cause-and-effect relationship that Judge Smith does. ${ }^{76}$ Unlike Judge Smith, however, he did not conclude from it that courts should limit their review ni a (probably futile) effort to coerce Congress into

snbset of Congress cannot be trusted to act as the whole body would. See Bruff, supra note 31, at 213-22.

70. See Hill, The Third House of Congress Versus the Fourth Branch of Government: The Impact of Congressional Committee Staff on Agency Regulatory Decision-Making, 19 J. MAR. L. REv. 247 (1986).

71. Cf. Martin, The Legislative Veto and the Responsible Exercise of Congressional Power, 68 VA. L. REV. 253 (1982).

Congress is far better suited for policy review of rules than for legal review, and probably engages in the former even when its [response] comes clothed in the language of the latter. The views of later legislators as to the intent of earlier Congresses are too easily colored by subsequent developments that were not even remotely within contemplation at the time of passage. For similar reasons, courts, when construing statutes, traditionally have viewed post-enactment statements by legislators or committees as poor indicators of the original statutory intent.

Id. at $277-78 \mathrm{n} .69$ (emphasis in original) (citations omitted).

72. Cf. D.C. Fed'n of Civic Ass'ns v. Volpe, 459 F.2d 1231, 1246 (D.C. Cir. 1971) (admonishing Secretary of Transportation that he must, in deciding whether to approve bridge route, consider only statutorily relevant,factors, instead of simply acceding to irrelevant demands of influential congressional committee chairman), cert. denied, 405 U.S. 1030 (1972).

73. See, e.g., Smith, supra note 1, at 449.

74. 541 F.2d 1 (D.C. Cir.), cert. denied, 426 U.S. 941 (1976).

75. Id. at 68 (Leventhal, J., concurring).

76. See supra notes 53-54 and accompanying text. 
making more policies itself. He appreciated that statutes conferring broad discretionary powers are an inescapable reality of modern society and that the legitimacy of those powers would be seriously weakened without some judicial participation. ${ }^{77}$

\section{CONCLUSION}

This brief response to Judge Smith's critique has probed only a few corners of the vast topic of judicial review of agency action. Much theoretical work remains to be done. At present we do not even have a generally accepted descriptive inodel of the courts' current review standards. ${ }^{78}$ Still less is there a consensus about the review standards that courts should use, although the literature already contains some excellent treatinents by proponents ${ }^{79}$ as well as opponents ${ }^{80}$ of active judicial review.

But even those observers who would favor a shift backwards, towards greater judicial deference, should question Judge Smith's position that intrusive judicial review of the merits of agency actions is fundannentally illegitimate, a sign of constitutional crisis. The review standards that courts apply to routine adıministrative decisions have not been seriously challenged as constitutionally excessive for at least half a century, ${ }^{81}$

77. Cf. Mashaw, supra note 57 , at 93,99 (judicial requirements of rationality help make delegations of authority desirable).

78. The ABA Administrative Law Section's "restatement" attempts to fill this gap. See Restatement Report, supra note 18.

79. See, e.g., Garland, supra note 30; Sunstein, supra note 64; Sunstein, In Defense of the Hard Look: Judicial Activism and Administrative Law, 7 HARV. J.L. \& PUB PoL'Y 51 (1984).

80. See, e.g., McGarity, Judicial Review of Scientific Rulemaking, SCI., Tech. \& HuMaN VALUES, Winter 1984, at 97; Scalia, supra note 61; Starr, Judicial Review in the Post-Chevron Era, 3 YALE J. REG. 283 (1986).

81. What constitutional law exists on the subject of excessive judicial review of agency decisions emerges most clearly from a pair of cases involving the Federal Radio Commission, the predecessor of the FCC. The Radio Act of 1927 authorized the Court of Appeals for the District of Columbia Circuit to revise the Commission's decisions in any manner it considered just. Federal Radio Comm'n v. General Electric Co., 281 U.S. 464, 467 (1930). The Supreme Court held that this broad revisory power was "administrative" rather than "judicial" and refused to take appellate jurisdiction in a case arising under the Act. Id. at 469-70. Congress responded to General Electric by amending the statute to permit a reviewing court nerely to consider whether the agency had made an error of law, whether the findings were supported by substantial evidence, and whether the findings were arbitrary or capricious. In Federal Radio Comm'n v. Nelson Bros. Bond \& Mortgage Co., 289 U.S. 266, 274-78 (1933), the Supreme Court pronounced all of these inquiries "judicial" and held that the problems noted in General Electric had been cured. See $4 \mathrm{~K}$. Davis, Administrative LAW TREATISE $\S 29.10$, at 180-83 (1st ed. 1958). Since then, this branch of constitutional law has been essentially quiescent. Compare Maryland v. United States, 460 U.S. 1001 (1983) (upholding without opinion judge's approval of consent decrec dismantling AT\&T) with id. at 1004-06 (Rehnquist, J., dissentimg) (expressing concern that the statute authorizing the district court to review antitrust settlement agreements might exceed article III limits on the judicial power).

To some degree, the legacy of General Electric survives in the general rule that when a court finds an adininistrative action unlawful, it must remand the action to the agency for reconsideration, 
and one doubts that the Supreme Court would reopen that line of inquiry today. ${ }^{82}$ In any event, Judge Smith has not convincingly supported his thesis that courts must refrain from any serious review of "decisions of will." Although the courts will never be a match for the executive in political decisionmaking, it is unrealistic to propose to exclude them entirely.

Despite some weaknesses in his arguments, however, Judge Smith's somber conclusion that judicial review has lost its moorings should not be put out of mind too readily. Existing standards of review call for a great deal of sophistication and prudential judgment in their application. Whatever one thinks of the courts' recent performance, it would be all too easy for tomorrow's judges to drift inadvertently into either abdication of meaningful review or usurpation of legitimate administrative discretion. As an old aphorism runs, "[ $[$ t]he optimist proclaims that we live in the best of all possible worlds; and the pessimist fears this is true." 83 To avoid confirming Judge Smith's pessimistic forecast, both courts and commentators will need to be on their guard against complacency in the years ahead.

instead of simply revising the agency's decision as the court deems best. See, e.g., NLRB v. Food Store Employees Local 347, 417 U.S. 1, 8-10 (1974); Federal Power Comm'n v. Idaho Power Co., 344 U.S. 17, 20-21 (1952); FCC v. Pottsville Broadcasting Co., 309 U.S. 134, 145-46 (1940). To this extent, Judge Smith is correct in saying that courts "must always be instruments of restraint [instead of creativity]." See Smith, supra note 1, at 445 . But this rule restricts only judicial remedies, not the review standards by which the legality of "decisions of will" will be determined. Even as a remedial principle, moreover, it has its exceptions. See Garland, supra note 30, at 562-75 (noting, for example, recent cases in which courts have ordered agencies to take statutorily mandated affirmative acts).

82. If anything, the live constitutional issue today is whether the courts' review in certain types of cases is sufficiently intensive to satisfy article III. See generally Monaghan, Constitutional Fact Review, 85 COLum. L. Rev. 229, 247-59 (1985).

83. J. Cabell, The Silver Stallion 1 I2 (I926). 